\title{
Pausing methotrexate improves immunogenicity of COVID- 19 vaccination in elderly patients with rheumatic diseases
}

Arumahandi de Silva $\mathrm{AN}^{1}+$, Frommert $\mathrm{LM}^{1}+$, Albach FN ${ }^{1}$, Klotsche $\mathrm{J}^{2}$, Scholz $\mathrm{V}^{1}$, Jeworowski $\mathrm{LM}^{3}$, Schwarz $T^{3}$, ten Hagen $A^{1}$, Zernicke $J^{1}$, Corman $V^{3,4}$, Drosten $C^{3}$, Burmester $\mathrm{GR}^{1} \dagger$, Biesen $\mathrm{R}^{1} \dagger$

${ }^{1}$ Department of Rheumatology and Clinical Immunology, Charité - Universitätsmedizin Berlin, corporate member of Freie Universität Berlin and Humboldt-Universität zu Berlin, Berlin, Germany

${ }^{2}$ German Rheumatism Research Center Berlin - a Leibniz Institute (DRFZ), Berlin, Germany

${ }^{3}$ Institute of Virology, Charité - Universitätsmedizin Berlin, Freie Universität Berlin and Humboldt-Universität zu Berlin, Berlin, Germany and German Centre for Infection Research (DZIF), Associated Partner Site, Berlin, Germany

${ }^{4}$ Labor Berlin, Charité - Vivantes $\mathrm{GmbH}$, Berlin, Germany

+ contributed equally

\section{Address correspondence and reprint request:}

Dr. med. Robert Biesen

Department of Rheumatology and Clinical Immunology

Charité University Hospital

Charitéplatz 1

D-10117 Berlin - Germany

E-mail: Robert.Biesen@charite.de 
medRxiv preprint doi: https://doi.org/10.1101/2021.11.17.21266441; this version posted February 23, 2022. The copyright holder for this preprint (which was not certified by peer review) is the author/funder, who has granted medRxiv a license to display the preprint in It is made available under a CC-BY-ND 4.0 International license .

\section{ABSTRACT}

Objective: To study the effect of methotrexate (MTX) and its discontinuation on the humoral immune response after COVID-19 vaccination in patients with autoimmune rheumatic diseases (AIRD).

Methods: In this retrospective study, neutralising SARS-CoV-2 antibodies were measured after second vaccination in 64 rheumatic patients on methotrexate therapy, 31 of whom temporarily paused medication without a fixed regimen. The control group consisted of 21 AIRD patients without immunosuppressive medication.

Results: MTX patients showed a significantly lower mean antibody response compared to AIRD patients without immunosuppressive therapy $(71.8 \%$ vs $92.4 \%, p<0.001)$. For patients taking MTX, age correlated negatively with immune response $(r=-0.49 ; p<0.001)$. All nine patients with antibody levels below the cut-off were older than 60 years. Patients who held MTX during at least one vaccination showed significantly higher mean neutralising antibody levels after second vaccination, compared to patients who continued MTX therapy during both vaccinations ( $83.1 \%$ vs $61.2 \%, p=0.001)$. This effect was particularly pronounced in patients older than 60 years ( $80.8 \%$ vs $51.9 \%, p=0.001$ ). The impact of the time period after vaccination was greater than of the time before vaccination with the critical cut-off being 10 days.

Conclusion: MTX reduces the immunogenicity of SARS-CoV-2 vaccination in an agedependent manner. Our data further suggest that holding MTX for at least 10 days after vaccination significantly improves the antibody response in patients over 60 years of age. 
medRxiv preprint doi: https://doi.org/10.1101/2021.11.17.21266441; this version posted February 23, 2022. The copyright holder for this preprint (which was not certified by peer review) is the author/funder, who has granted medRxiv a license to display the preprint in It is made available under a CC-BY-ND 4.0 International license .

\section{INTRODUCTION}

Until November 2021, SARS-CoV-2 had infected at least 250 million people worldwide and caused about 5 million deaths in a 23-month period ${ }^{1}$. At the same time, enormous knowledge about SARS-CoV-2 and the related disease COVID-19 have been generated and the possibilities for prevention, diagnostics and treatments have improved remarkably.

Methotrexate (MTX) has been used for decades to treat a wide variety of immune-mediated diseases in oncology, rheumatology, dermatology, gastroenterology, and neurology. Following prednisolone, MTX is the most prescribed anti-inflammatory drug worldwide with 1 million MTX patients in the US alone ${ }^{2}$.

Various immunosuppressants reduce the immune response after COVID-19 vaccination ${ }^{3}$.. Although several research groups have recently described a reduced vaccination response under MTX ${ }^{45}$, in some cohorts MTX had no negative influence ${ }^{67}$. Most of these studies did not collect data on whether or not patients had paused MTX during vaccinations, although more than one-third of patients had modified their medication on their own or on the advice of their rheumatologist, according to a recent survey ${ }^{8}$. The discontinuation of immunosuppressive medication can improve the vaccination response as recently shown for mycophenolate ${ }^{9}$.

A reduced vaccination response under MTX was first described in 2016 for influenza vaccination ${ }^{10}$. Follow-up data showed the increase in humoral immune response when pausing MTX two weeks before and after vaccination or only two weeks after vaccination ${ }^{11}{ }^{12}$. The time after and not before vaccination was decisive ${ }^{13}$. However, data regarding MTX-hold during COVID-19 vaccination are still lacking, which is why current guidelines are based on experience with influenza vaccines, not considering mRNA based technology used for COVID-19 vaccinations. Although current guidelines by the American College of Rheumatology as well as the German Society for Rheumatology recommend holding MTX one to two weeks after COVID-19 vaccination ${ }^{14}$, , the EULAR does not recommend pausing MTX ${ }^{16}$.

Therefore, our main objective was to study the effect of MTX and its discontinuation on the humoral immune response after COVID-19 vaccination in patients with autoimmune rheumatic diseases (AIRD). Secondary objective was to determine additional influencing factors on antibody response in these patients. 
medRxiv preprint doi: https://doi.org/10.1101/2021.11.17.21266441; this version posted February 23, 2022. The copyright holder for this preprint (which was not certified by peer review) is the author/funder, who has granted medRxiv a license to display the preprint in It is made available under a CC-BY-ND 4.0 International license .

\section{METHODS}

\section{Study design and participants}

This is a retrospective sub-analysis of the VACCIMMUN Study, which is an observational cohort study among patients with autoimmune rheumatic diseases (AIRD) at the Charité Department for Rheumatology and Clinical Immunology in Berlin, Germany. Participants were recruited between April and September 2021 and had to meet the following inclusion criteria: age 18 years or older, AIRD diagnosis and vaccination with a COVID-19 vaccine authorised for use in Germany. For this analysis, only AIRD patients under MTX therapy were considered, receiving either only MTX or MTX combined with low dose prednisolone (defined as $\leq 5 \mathrm{mg} / \mathrm{d}$ ), TNF $\alpha$ Inhibitors, hydroxychloroquine, leflunomide, IL-17 or IL-12/23 inhibitors, since these immunosuppressive comedications are not known to have a remarkable impact on the immune response after vaccination ${ }^{15}$. Additionally, AIRD patients who were vaccinated under no immunosuppressive therapy served as controls. Information regarding medical history including COVID-19 vaccination status and immunosuppressive therapy were provided directly by patients and additionally validated with medical records. At the time of blood drawing, patients were asked about their MTX intake schedule around vaccinations. The decision on continuing or holding MTX was made by the patient or the attending physician and was only observed in the study. Patients who reported to have changed their MTX-intake schedule resulting in an MTX-interval longer than 7 days around first or second vaccination were compared to patients who continued MTX therapy throughout both vaccinations. This study was ethically approved by the Regional Office for Health and Social Affairs Berlin, Germany (21/0098-IV E 13). All patients provided written informed consent.

\section{Laboratory analyses}

Antibody response was measured predominantly about two weeks after the second dose of vaccination with maximum range from 11 to 112 days. Neutralising antibody levels were assessed using a surrogate virus neutralisation test (cPass Neutralisation, Medac GmbH, Wedel, Germany) ${ }^{17}$. Following the manufacturer's protocol, patients who reached inhibition rates greater than or equal to $30 \%$ were considered to have demonstrated a SARS-CoV-2 specific humoral response and are further defined as responders, while patients with inhibition rates $<30 \%$ are defined as non-responders. Additionally, IgG antibodies against nucleocapsid, 
medRxiv preprint doi: https://doi.org/10.1101/2021.11.17.21266441; this version posted February 23, 2022. The copyright holder for this preprint (which was not certified by peer review) is the author/funder, who has granted medRxiv a license to display the preprint in It is made available under a CC-BY-ND 4.0 International license .

receptor binding domain $(\mathrm{RBD})$, full spike and the $\mathrm{S} 1$ domain of the spike protein were tested using SeraSpot ${ }^{\circledR}$ Anti-SARS-CoV-2 lgG microarray-based immunoassay (Seramun Diagnostica $\mathrm{GmbH}$, Heidesee, Germany) and served here for further validation purposes. Hence, all calculations were additionally performed using anti-RBD-lgG levels and can be found in the supplements. The threshold for reactivity for anti-SARS-CoV-2 IgG levels was set at $>1.00$ Signal/Cut-off (S/CO) in accordance with manufacturer's protocol.

\section{Statistical analysis}

Descriptive statistics included mean with standard deviation and absolute and relative frequencies. The exact unconditional z-pooled test ${ }^{18}$ and $\mathrm{Chi}^{2}$ test were applied for binary and categorical data and the unpaired t test with Welch's correction for continuously distributed variables to perform hypotheses tests for group differences, as appropriate. The likelihood of response to vaccination was modelled by a Poisson generalized linear model with robust error variances and log link function including the covariates age, gender, MTX monotherapy, MTX in combination with prednisolone, MTX in combination with other DMARDs \pm prednisolone, MTX-hold and vaccine interval as suggested by Zou ${ }^{19}$. These covariates were selected based on the theoretical assumption that they could affect vaccination success and on the results of the univariate analysis. The association between antibody results (dependent variables antiRBD-lgG concentrations or neutralising capacity) and the covariates age, gender, MTX monotherapy, MTX in combination with prednisolone and MTX in combination with other DMARDs \pm prednisolone, MTX-hold, vaccine interval and timing and duration of MTX-hold was estimated by a linear regression model. The unstandardized and standardized beta coefficients were calculated for linear regression analyses in order to compare the strengths of association between parameters. The area under curve was calculated after fitting a logistic regression model to provide a measure of strengths of association for dichotomous outcomes. The Youden index was used to estimate thresholds for age and time of MTX break before and after vaccination from receiver-operating characteristics. Statistical analyses were performed using Graphpad Prism 9.2.0, R 4.1.2 and STATA 12.1.

\section{Patient and public involvement}


medRxiv preprint doi: https://doi.org/10.1101/2021.11.17.21266441; this version posted February 23, 2022. The copyright holder for this preprint (which was not certified by peer review) is the author/funder, who has granted medRxiv a license to display the preprint in It is made available under a CC-BY-ND 4.0 International license

This study aimed to provide evidence for future recommendations due to questions asked regarding MTX intake by patients and physicians. However, patients and the public were not directly involved in process of designing. 
medRxiv preprint doi: https://doi.org/10.1101/2021.11.17.21266441; this version posted February 23, 2022. The copyright holder for this preprint (which was not certified by peer review) is the author/funder, who has granted medRxiv a license to display the preprint in

\section{RESULTS}

\section{Patient characteristics}

Of 73 eligible patients receiving MTX, nine were excluded due to unacceptable immunosuppressive comedication, irregular medication regimens and unclassifiable MTXhold. The final cohort consisted of 64 AIRD patients taking MTX (mean age 61 years, $70.3 \%$ women) and 21 rheumatic patients who did not receive any kind of immunosuppressive therapy as a control group (mean age 61, $90.5 \%$ women). Detailed clinical characterisation is given in supplementary table 1. Patients in the no-therapy group were of similar age and BMI, but more often female. They were less often diagnosed with rheumatoid arthritis and more often with systemic sclerosis.

Of 64 MTX patients, 31 patients reported to have held MTX for at least one vaccination (MTXhold) while 33 patients had continued their MTX therapy without any interruption (MTX continued, table 1). Blood sampling occurred slightly earlier in the MTX-hold group than in the MTX continued group. There were no significant differences between these two groups regarding age, BMI, distribution of sex, vaccination regimes, diagnoses and immunosuppressive comedications (table 1).

\section{MTX reduces vaccination response}

AIRD patients without immunosuppressive therapy showed a significantly higher neutralising capacity (mean $92.4 \%$, SD: 8.6) than AIRD patients taking MTX (mean $71.8 \%$, SD: 28.3, p< 0.001 , figure 1 , supplementary figure 1 for anti-RBD-lgG). This was still the case after adjusting for the possible confounders gender, age, vaccine regime and vaccine interval, AIRD diagnosis and duration from second vaccination to blood draw in a logistic regression (for neutralising capacity: beta $=-19.5,95 \% \mathrm{Cl}:-31.4 ;-7.7, \mathrm{p}=0.002$; for anti-RBD-lgG: beta $=-1.61,95 \% \mathrm{Cl}$ $3.03 ;-0.18, p=0.028)$. None of the patients without immunosuppressive therapy were classified as non-responders (defined by neutralisation activity < $30 \%$ ), compared to $14.1 \%(n=9)$ among MTX patients. Taking patients without immunosuppressive therapy in our cohort as a reference group for a typical antibody response after vaccination, the threshold for a notaltered inhibition rate could be set at $87.6 \%$ (AUC 0.75, Youden index 49.9). Accordingly, 38 of 64 MTX patients (59.4\%) demonstrated a lower antibody response after two vaccinations compared to an untreated group of AIRD patients. 
medRxiv preprint doi: https://doi.org/10.1101/2021.11.17.21266441; this version posted February 23, 2022. The copyright holder for this preprint (which was not certified by peer review) is the author/funder, who has granted medRxiv a license to display the preprint in It is made available under a CC-BY-ND 4.0 International license .

\section{Factors influencing antibody response in MTX patients}

To identify factors influencing the antibody response under MTX we compared COVID-19 vaccination responders ( $n=55,85.9 \%)$ and non-responders ( $n=9,14.1 \%)$ defined by neutralisation activity. Both groups were comparable in BMI, vaccine type, MTX application form, additional prednisolone intake, time of blood draw and immunosuppressive comedication (table 2). Dosage of MTX was not significantly associated with vaccination success (Spearman rank correlation, $r=-0.02$, $p$ value $=0.867$ ). However, a higher neutralisation capacity was significantly associated with young age, MTX-hold and female gender in univariate analysis (table 2) and multivariable analysis (table 3). If classification into responders and non-responders was based on anti-RBD-lgG results, 13 patients fall into the nonresponder group. While the effect of age and MTX-hold were still significant using anti-RBDIgG levels, this was not the case for gender (supplementary table 2, table 3). A longer vaccine interval was associated with an adequate humoral response to vaccination in our cohort (significant in $t$ test for neutralising capacity and anti-RBD-IgG levels; only significant in multivariable analysis for anti-RBD-lgG levels). In the following, we will analyse the effect of age and MTX-hold in more detail.

\section{Effect of MTX-hold and age}

Patients who had changed their MTX intake schedule for at least one vaccination showed a significantly higher antibody response than patients who continued their MTX intake $(p=0.001$, figure $2 \mathrm{~A}$, supplementary figure $2 \mathrm{~A}$ for anti-RBD-IgG). Mean neutralisation was $61.2 \%$ for patients who continued their therapy and $83.1 \%$ for patients who held MTX (table 1). There was only one non-responder (3.2\%) in the MTX-hold group, while there were eight nonresponders (24.2\%) in the MTX continued group. The effect of pause persisted in patients with MTX monotherapy, indicating that this effect cannot be explained by the existing comedication (supplementary figure 3).

Vaccination response correlated significantly with age (Spearman rank correlation, -0.49, $p<0.001$, figure 3, supplementary figure 4 for anti-RBD-lgG). No patient younger than 60 years was classified a non-responder which is why we further distinguished the MTX hold and continued groups into patients older and younger than 60 years of age (figure 2B, supplementary figure $2 B$ for anti-RBD- $\lg G)$. Considering only patients who continued their MTX intake, patients $\geq 60$ years of age (mean $51.9 \%$ ) had a 30.7 percentage points lower mean 
medRxiv preprint doi: https://doi.org/10.1101/2021.11.17.21266441; this version posted February 23,2022 . The copyright holder for this preprint (which was not certified by peer review) is the author/funder, who has granted medRxiv a license to display the preprint in

It is made available under a CC-BY-ND 4.0 International license .

inhibition rate than patients < 60 years (mean $82.6 \%$ ). Vice versa, neutralisation levels were 28.9 percentage points higher in patients older than 60 years who held MTX (mean $80.8 \%$ ) compared to those who continued MTX (mean $51.9 \%$ ). In contrast, when regarding patients under 60 years there were no significant differences in neutralisation rates between patients who held or continued MTX therapy.

\section{Effect of timing and duration of MTX-hold}

In the following we considered all 64 patients and analysed the MTX-interval at the time of vaccination, which was defined by the time between last MTX intake and vaccination (time before vaccination $=T_{\mathrm{BV}}$ ) and the time between vaccination and re-intake of MTX (time after vaccination $=T_{A V}$, figure 4). One patient could not recall on which day MTX was taken and was therefore not considered for calculations of $T_{B V}$ and $T_{A V}$. We found that the duration of the MTX-interval ( $\left.T_{B V}+T_{A V}\right)$ significantly correlates with neutralising capacity (Spearman rank correlation, $r=0.47, p<0.001)$. We further analysed which of these time periods is most likely to determine antibody response. By using linear regression analysis, we found time after vaccination $\left(T_{A V}\right)$ to be highly significant for adequate neutralisation rate and anti-RBD-lgG concentration in the elderly, but not for younger patients (table 4). Here, ten days between vaccination and MTX re-intake ( $\left.T_{A V}\right)$ were determined as the critical cut-off based on the Youden index from receiver operating characteristic curve. 
medRxiv preprint doi: https://doi.org/10.1101/2021.11.17.21266441; this version posted February 23, 2022. The copyright holder for this preprint (which was not certified by peer review) is the author/funder, who has granted medRxiv a license to display the preprint in It is made available under a CC-BY-ND 4.0 International license .

\section{DISCUSSION}

Our study found a reduced COVID-19 vaccination response in MTX patients, demonstrates the effect of age and provides first data on the effect of MTX-hold around COVID-19 vaccinations. Using neutralising capacity and the manufacturer's cut-off, we found a slightly higher rate of vaccination responders among patients taking MTX (85.9\%) than previously reported (47- 72 $\%{ }^{4}$. Using ROC analysis and an untreated control group, we determined an adapted cut-off value and found adequate immune response in only $40.6 \%$ of MTX patients. Hence, we confirmed the observations from previous studies that the antibody response is reduced under MTX therapy ${ }^{45}$. In contrast, others described no effect of MTX on vaccination response ${ }^{67}$. These varying results may be due to a lower effect size of MTX on vaccination response compared to other immunosuppressive therapies such as rituximab or mycophenolate, different test systems and statistical analyses used and other influencing factors such as age and pausing of MTX therapy.

We determined young age, MTX-hold and longer vaccine interval as the main factors improving antibody response after vaccination. The negative influence of age on vaccination response was already known ${ }^{20} 21$. However, the consideration of age was not yet differentiated in previous studies investigating immune response under MTX therapy. Therefore our data allows the assumption that continuous MTX intake and old age are potentiating negative factors. The positive effect of a longer vaccine interval on humoral immune response is in line with previously published works ${ }^{22} 23$. These results were statistically significant in t test for both antibody testing systems, but in the generalized linear model only for anti-RBD-IgG levels. This discrepancy is likely due to the higher statistical power of the $t$ test.

Patients who held MTX for at least one vaccination had a significantly higher immune response than those who continued MTX, which has not yet been described for COVID-19 vaccination. Nevertheless, our findings are in line with studies by Park et al. investigating the effect of MTXhold on the immune response to influenza vaccination ${ }^{11}$. More detailed analysis showed that time after vaccination is crucial, which was also described by Park et al. who recommended a MTX discontinuation of two weeks after influenza vaccination ${ }^{12}{ }^{13}$. In our study, we found a minimum time of 10 days after vaccination to be critical for immune response in patients $\geq 60$ 
medRxiv preprint doi: https://doi.org/10.1101/2021.11.17.21266441; this version posted February 23, 2022. The copyright holder for this preprint (which was not certified by peer review) is the author/funder, who has granted medRxiv a license to display the preprint in perpetuity.
It is made available under a CC-BY-ND 4.0 International license .

years. Additionally, the positive effect of MTX-hold was only statistically significant for patients 60 years or older. An effect also in younger patients might be observed in a larger cohort.

A strength of our study was that we validated all our neutralisation test results with an additional test system measuring anti-RBD-lgG levels. The latter defined four more patients as non-responders compared to the neutralisation test. This small number of conflicting test results is to be expected when using different test systems. The uneven distribution of gender among patients who had conflicting test results caused our analyses to suggest a significant influence of gender on the neutralisation result. This may be due to a statistical artifact and the effect of gender should be interpreted with caution.

This study has limitations. Since data regarding the MTX intake schedule during vaccination was assessed retrospectively, recall bias cannot be excluded. Due to our small sample size, we had to limit factors in the multivariable logistic regression modelling, which may lead to bias and residual confounding. For instance, confounding due to duration from vaccination to blood sampling, disease activity or AIRD diagnosis cannot with certainty be excluded in our analyses. We did not assess disease activity and safety of pausing MTX in our cohort, but current data do not indicate a significantly higher flare occurrence or disease activity in association with MTX discontinuation of two weeks ${ }^{24}$. Also, T-cell-response was not part of our study design. However, according to current studies, it can be assumed that measuring humoral vaccination response is an adequate mean to determine vaccine immunogenicity ${ }^{25}$ and that higher antibody levels correlate with a better clinical outcome ${ }^{26} 27$. To address these limitations, a randomised controlled clinical trial to generate evidence for optimal management of MTX in COVID-19 vaccinations should be performed.

In conclusion, we present real-world data that is of clinical relevance regarding ongoing booster vaccinations. We determined age and MTX-hold as the main factors influencing antibody response during SARS-CoV-2 vaccinations and both aspects should be considered when discussing MTX regimens. Our data suggest that, if possible, patients older than 60 years of age should hold MTX for at least 10 days after receiving a COVID-19-vaccination. 
medRxiv preprint doi: https://doi.org/10.1101/2021.11.17.21266441; this version posted February 23, 2022. The copyright holder for this preprint (which was not certified by peer review) is the author/funder, who has granted medRxiv a license to display the preprint in It is made available under a CC-BY-ND 4.0 International license .

\section{Key messages}

\section{What is already known about this subject?}

- Patients receiving methotrexate (MTX) have a reduced immune response after COVID19 vaccination and holding MTX has shown to increase the immunogenicity after influenza vaccination.

- Yet, no previous studies have analysed the effect of MTX-hold for COVID-19 vaccination.

\section{What does this study add?}

- This study identified old age ( $\geq 60$ years), short vaccine interval and MTX continuation as critical factors for an inadequate antibody response.

- We found a minimum of 10 days between vaccination and re-intake of MTX as the critical threshold to increase immunogenicity for patients $\geq 60$ years of age.

\section{How might this impact on clinical practise or future developments?}

- In regard of ongoing booster vaccinations, our data suggest that especially older MTX patients should hold MTX for at least 10 days after receiving a COVID-19 vaccination. 
medRxiv preprint doi: https://doi.org/10.1101/2021.11.17.21266441; this version posted February 23,2022 . The copyright holder for this preprint (which was not certified by peer review) is the author/funder, who has granted medRxiv a license to display the preprint in It is made available under a CC-BY-ND 4.0 International license .

Acknowledgements: We would like to thank Tanja Braun and Vera Höhne-Zimmer for their support in obtaining the ethics vote and for their organisational support.

Contributors: All authors contributed to the acquisition, analysis or interpretation of data and critical revision of the manuscript for important intellectual content. RB had full access to all the data in the study and takes responsibility for the integrity of the data and the accuracy of the data analysis. FA, JZ, GB, RB were involved in the study design. Sample collection was done by $A S, L F, F A, V S, A H, J Z$. Experiments and data analysis were performed by AS, LF, FA, JK, LJ, $\mathrm{TS}, J Z, V C, C D, G B$ and RB. AS, LF, FA and RB were responsible for tables and figures. Data interpretation was done by all authors. Statistical analyses were done by AS, LF, FA, JK and RB. Writing of the manuscript were performed by AS, LF, FA, JK, GB and RB. All authors were involved in critical proof reading of the manuscript.

Competing interests: VC is named together with Euroimmun $\mathrm{GmbH}$ on a patent application filed recently regarding the diagnostic of SARS-CoV-2 by antibody testing.

Patient consent: All patients provided written informed consent.

Funding: This study did not receive any funding.

Ethics approval: The Berlin State Office for Health and Social Affairs (Turmstrasse 21, 10559 Berlin, Germany) has approved this study under file number 21/0098-IV E 13.

Data sharing statement: Data are available on reasonable request. All data relevant to the study are included in the article or uploaded as online supplemental information. 
medRxiv preprint doi: https://doi.org/10.1101/2021.11.17.21266441; this version posted February 23, 2022. The copyright holder for this preprint (which was not certified by peer review) is the author/funder, who has granted medRxiv a license to display the preprint in It is made available under a CC-BY-ND 4.0 International license .

\section{REFERENCES}

1. Ritchie H, Mathieu E, Rodés-Guirao L, et al. Coronavirus Pandemic (COVID-19): Our World in Data; 2020 [Available from: https://ourworldindata.org/coronavirus-data accessed 14.11.2021 2021.

2. Kane S. Methotrexate 2021 [updated September 15, 2021. Available from: https://clincalc.com/DrugStats/Drugs/Methotrexate accessed November 14, 2021.

3. Friedman MA, Curtis JR, Winthrop KL. Impact of disease-modifying antirheumatic drugs on vaccine immunogenicity in patients with inflammatory rheumatic and musculoskeletal diseases. Ann Rheum Dis 2021;80(10):1255-65. doi: 10.1136/annrheumdis-2021221244 [published Online First: 2021/09/09]

4. Mahil SK, Bechman K, Raharja A, et al. The effect of methotrexate and targeted immunosuppression on humoral and cellular immune responses to the COVID-19 vaccine BNT162b2: a cohort study. The Lancet Rheumatology 2021;3(9):e627-e37.

5. Haberman RH, Herati R, Simon D, et al. Methotrexate hampers immunogenicity to BNT162b2 mRNA COVID-19 vaccine in immune-mediated inflammatory disease. Annals of the Rheumatic Diseases 2021

6. Braun-Moscovici Y, Kaplan M, Braun M, et al. Disease activity and humoral response in patients with inflammatory rheumatic diseases after two doses of the Pfizer mRNA vaccine against SARS-CoV-2. Ann Rheum Dis 2021;80(10):1317-21. doi: 10.1136/annrheumdis-2021-220503 [published Online First: 2021/06/20]

7. Ruddy JA, Connolly CM, Boyarsky BJ, et al. High antibody response to two-dose SARS-CoV2 messenger RNA vaccination in patients with rheumatic and musculoskeletal diseases. Annals of the Rheumatic Diseases 2021;80(10):1351-52. doi:

10.1136/annrheumdis-2021-220656

8. Barbhaiya M, Levine JM, Bykerk VP, et al. Immunomodulatory and immunosuppressive medication modification among patients with rheumatic diseases at the time of COVID-19 vaccination. Lancet Rheumatol 2021 doi: 10.1016/S2665-9913(21)00372-6 [published Online First: 20211208]

9. Connolly CM, Chiang TP-Y, Boyarsky BJ, et al. Temporary hold of mycophenolate augments humoral response to SARS-CoV-2 vaccination in patients with rheumatic and musculoskeletal diseases: a case series. Annals of the Rheumatic Diseases 2021 
medRxiv preprint doi: https://doi.org/10.1101/2021.11.17.21266441; this version posted February 23, 2022. The copyright holder for this preprint (which was not certified by peer review) is the author/funder, who has granted medRxiv a license to display the preprint in

10. Winthrop KL, Silverfield J, Racewicz A, et al. The effect of tofacitinib on pneumococcal and influenza vaccine responses in rheumatoid arthritis. Annals of the Rheumatic Diseases 2016;75(4):687-95. doi: 10.1136/annrheumdis-2014-207191

11. Park JK, Lee YJ, Shin K, et al. Impact of temporary methotrexate discontinuation for 2 weeks on immunogenicity of seasonal influenza vaccination in patients with rheumatoid arthritis: a randomised clinical trial. Ann Rheum Dis 2018;77(6):898-904. doi: 10.1136/annrheumdis-2018-213222 [published Online First: 2018/03/25]

12. Park JK, Lee MA, Lee EY, et al. Effect of methotrexate discontinuation on efficacy of seasonal influenza vaccination in patients with rheumatoid arthritis: a randomised clinical trial. Annals of the Rheumatic Diseases 2017;76(9):1559-65. doi: 10.1136/annrheumdis-2017-211128

13. Park JK, Choi Y, Winthrop KL, et al. Optimal time between the last methotrexate administration and seasonal influenza vaccination in rheumatoid arthritis: post hoc analysis of a randomised clinical trial. Annals of the rheumatic diseases 2019;78(9):1283-84.

14. Curtis JR, Johnson SR, Anthony DD, et al. American College of Rheumatology: COVID-19 Vaccine Clinical Guidance Summary for Patients with Rheumatic and Musculoskeletal Diseases: Version 4. 2021

15. Specker C, Aries P, Braun J, et al. Aktualisierte Handlungsempfehlungen der Deutschen Gesellschaft für Rheumatologie für die Betreuung von Patienten mit entzündlichrheumatischen Erkrankungen im Rahmen der SARS-CoV-2/COVID-19-Pandemie einschließlich Empfehlungen zur COVID-19-Impfung. Zeitschrift für Rheumatologie 2021;80(6):570-87. doi: 10.1007/s00393-021-01056-6

16. EULAR. EULAR View-points on SARS-CoV-2 vaccination in patients with RMDs 2021 [updated December 2021. Available from: https://www.eular.org/eular sars cov 2 vaccination rmd patients.cfm.

17. Tan CW, Chia WN, Qin X, et al. A SARS-CoV-2 surrogate virus neutralization test based on antibody-mediated blockage of ACE2-spike protein-protein interaction. Nature biotechnology 2020;38(9):1073-78.

18. Lydersen $S$, Langaas $M$, Bakke $\varnothing$. The exact unconditional z-pooled test for equality of two binomial probabilities: optimal choice of the Berger and Boos confidence coefficient. 
medRxiv preprint doi: https://doi.org/10.1101/2021.11.17.21266441; this version posted February 23, 2022. The copyright holder for this preprint (which was not certified by peer review) is the author/funder, who has granted medRxiv a license to display the preprint in It is made available under a CC-BY-ND 4.0 International license .

Journal of Statistical Computation and Simulation 2012;82(9):1311-16. doi: 10.1080/00949655.2011.579969

19. Zou G. A modified poisson regression approach to prospective studies with binary data. Am J Epidemiol 2004;159(7):702-6. doi: 10.1093/aje/kwh090 [published Online First: 2004/03/23]

20. Schwarz T, Tober-Lau P, Hillus D, et al. Delayed antibody and T-cell response to BNT162b2 vaccination in the elderly, Germany. Emerging Infectious Diseases 2021;27(8):2174.

21. Muller L, Andree M, Moskorz W, et al. Age-dependent immune response to the Biontech/Pfizer BNT162b2 COVID-19 vaccination. Clin Infect Dis 2021 doi: 10.1093/cid/ciab381 [published Online First: 20210427]

22. Payne RP, Longet $S$, Austin JA, et al. Immunogenicity of standard and extended dosing intervals of BNT162b2 mRNA vaccine. Cell 2021;184(23):5699-714.e11. doi: https://doi.org/10.1016/j.cell.2021.10.011

23. Grunau B, Goldfarb DM, Asamoah-Boaheng M, et al. Immunogenicity of Extended mRNA SARS-CoV-2 Vaccine Dosing Intervals. JAMA 2022;327(3):279-81. doi: 10.1001/jama.2021.21921

24. Park JK, Kim MJ, Choi Y, et al. Effect of short-term methotrexate discontinuation on rheumatoid arthritis disease activity: post-hoc analysis of two randomized trials. Clinical rheumatology 2020;39(2):375-79.

25. Khoury DS, Cromer D, Reynaldi A, et al. Neutralizing antibody levels are highly predictive of immune protection from symptomatic SARS-CoV-2 infection. Nature medicine 2021:1-7.

26. Feng $S$, Phillips DJ, White $T$, et al. Correlates of protection against symptomatic and asymptomatic SARS-CoV-2 infection. Nat Med 2021;27(11):2032-40. doi: 10.1038/s41591-021-01540-1 [published Online First: 20210929]

27. Gilbert PB, Montefiori DC, McDermott A, et al. Immune Correlates Analysis of the mRNA1273 COVID-19 Vaccine Efficacy Trial. medRxiv 2021:2021.08.09.21261290 [Preprint]. August 15, 2021 [cited 2022 Feb 04]. doi: 10.1101/2021.08.09.21261290 
medRxiv preprint doi: https://doi.org/10.1101/2021.11.17.21266441; this version posted February 23, 2022. The copyright holder for this preprint (which was not certified by peer review) is the author/funder, who has granted medRxiv a license to display the preprint in

It is made available under a CC-BY-ND 4.0 International license .

\section{Tables}

Table 1: Characteristics of MTX patients who held and continued MTX

\begin{tabular}{|c|c|c|c|c|}
\hline & $\begin{array}{l}\text { MTX continued } \\
\qquad(n=33)\end{array}$ & $\begin{array}{l}\text { MTX-hold } \\
(n=31)\end{array}$ & $\begin{array}{c}\text { MTX all } \\
(n=64)\end{array}$ & P value ${ }^{*}$ \\
\hline Age, mean (SD) & $62.4(14.2)$ & $59.6(11.1)$ & $61.1(12.8)$ & 0.391 \\
\hline Female, n (\%) & $21(63.6)$ & $24(77.4)$ & $45(70.3)$ & 0.251 \\
\hline BMI, mean (SD) & $26.4(4.52)$ & $24.7(3.30)$ & $25.6(4.03)$ & 0.102 \\
\hline Rheumatic diagnosis & & & & 0.759 \\
\hline Rheumatoid arthritis, n (\%) & $21(63.6)$ & $23(74.2)$ & $44(68.8)$ & \\
\hline Psoriatic arthritis, n (\%) & $5(15.2)$ & $2(6.5)$ & $7(10.9)$ & \\
\hline Others, $\mathrm{n}(\%)^{+}$ & $7(21.2)$ & $6(19.4)$ & $13(20.3)$ & \\
\hline Medication & & & & 0.553 \\
\hline MTX-Mono, n (\%) & $14(42.4)$ & $12(38.7)$ & $26(40.6)$ & \\
\hline MTX+prednisolone, n (\%) & 7 (21.2) & $5(16.1)$ & $12(18.8)$ & \\
\hline $\mathrm{MTX}+\mathrm{Anti}-\mathrm{TNF} \alpha, \mathrm{n}(\%)^{\ddagger}$ & $4(12.1)$ & $7(22.6)$ & $11(17.2)$ & \\
\hline MTX+Anti-TNF $\alpha+$ prednisolone, n (\%) & $5(15.2)$ & $2(6.5)$ & $7(10.9)$ & \\
\hline MTX+others, $\mathrm{n}(\%)^{\S}$ & $3(9.1)$ & $5(16.1)$ & $8(12.5)$ & \\
\hline Additional prednisolone, n (\%) & $12(36.4)$ & $8(25.8)$ & $20(31.3)$ & 0.377 \\
\hline Prednisolone dose $[\mathrm{mg} / \mathrm{d}]$, mean (SD) & $3.0(1.8)$ & $2.6(1.1)$ & $2.9(1.6)$ & 0.572 \\
\hline MTX dose [mg/week], mean (SD) & $13.2(4.5)$ & $13.1(4.1)$ & $13.2(4.3)$ & 0.973 \\
\hline MTX oral application, n (\%) & $16(48.5)$ & $10(32.3)$ & $26(40.6)$ & 0.205 \\
\hline Vaccination & & & & 0.896 \\
\hline BNT162b2, n (\%) & $24(72.7)$ & $23(74.2)$ & $47(73.4)$ & \\
\hline mRNA-1273, n (\%) & $5(15.2)$ & $3(9.7)$ & $8(12.5)$ & \\
\hline AZD1222, n (\%) & $3(9.1)$ & $4(12.9)$ & 7 (10.9) & \\
\hline AZD1222 + BNT162b2, n (\%) & $1(3.0)$ & $1(3.2)$ & $2(3.1)$ & \\
\hline vaccine interval in days, mean (SD) & $39.0(14.8)$ & $41.9(15.3)$ & $40.4(15.0)$ & 0.444 \\
\hline \multicolumn{5}{|l|}{ Immune Response } \\
\hline days from $2^{\text {nd }}$ vaccination, mean (SD) & $35(23)$ & $28(22)$ & $32(22)$ & 0.237 \\
\hline Anti-RBD-lgG [S/CO], mean (SD) & $3.7(3.4)$ & $6.3(2.6)$ & $5.0(3.3)$ & 0.001 \\
\hline Neutralising capacity [\%], mean (SD) & $61.2(30.2)$ & $83.1(21.2)$ & $71.8(28.3)$ & 0.001 \\
\hline Responders, neutralisation capacity, n (\%) ${ }^{\star \star}$ & $25(75.8)$ & $30(96.8)$ & $55(85.9)$ & 0.017 \\
\hline Responders, anti-RBD-lgG response, $\mathrm{n}(\%)^{\dagger+}$ & $21(63.6)$ & $30(96.8)$ & $51(79.7)$ & 0.002 \\
\hline \multicolumn{5}{|l|}{ MTX-hold } \\
\hline for both vaccinations, $\mathrm{n}(\%)$ & NA & $24(77.4)$ & & \\
\hline
\end{tabular}

\footnotetext{
* $\mathrm{P}$ values compare MTX continued and MTX-hold and were calculated using the exact unconditional z-pooled test for binary variables (female, additional prednisolone, MTX oral application, Responders neutralisation capacity, Responders anti-RBD-IgG response), $\mathrm{Chi}^{2}$ test for categorical variables (rheumatic diagnosis, medication, vaccination) and unpaired $\mathrm{t}$ test with Welch's correction for continuous variables.

${ }^{\dagger}$ For MTX continued: ANCA-associated vasculitis $(n=1)$, Axial spondyloarthritis $(n=1)$, Polymyalgia rheumatica $(n=2)$, Systemic sclerosis ( $n=1)$, Myositis $(n=1)$, Systemic lupus erythematosus $(n=1)$. For MTX-hold: Axial spondyloarthritis $(n=1)$, Polymyalgia rheumatica $(n=1)$, Primary Sjogren's syndrome $(n=1)$, Systemic sclerosis $(n=2)$, Myositis $(n=1)$.

${ }^{\ddagger}$ Adalimumab, Certolizumab, Etanercept, Golimumab, Infliximab.

${ }^{\S}$ For MTX continued: hydroxychloroquine $(n=1)$, secukinumab (IL-17-inhibitor, $\left.n=1\right)$, ustekinumab (IL-12/23-inhibitor, $\left.n=1\right)$. For MTX-hold: hydroxychloroquine $(n=1)$, leflunomide $(n=2)$, leflunomide+prednisolone $(n=1)$, secukinumab (IL-17-inhibitor, $n=1)$.

${ }^{* *}$ Defined as neutralising capacity against SARS-CoV-2 $\geq 30 \%$.

${ }^{++}$Defined as anti-RBD-IgG levels > 1.0 S/CO.

MTX, methotrexate.
} 
medRxiv preprint doi: https://doi.org/10.1101/2021.11.17.21266441; this version posted February 23, 2022. The copyright holder for this preprint (which was not certified by peer review) is the author/funder, who has granted medRxiv a license to display the preprint in

It is made available under a CC-BY-ND 4.0 International license .

for only the $1^{\text {st }}$ vaccination, $\mathrm{n}(\%)$

for only the $2^{\text {nd }}$ vaccination, $n$ (\%)

duration of MTX-hold for 1st vaccination [days], mean (SD)

duration of MTX-hold for 2nd vaccination [days], mean (SD)

\begin{tabular}{|c|c|c|}
\hline NA & $2(6.5)$ & \\
\hline NA & $5(16.1)$ & \\
\hline NA & $15.1(6.6)$ & \\
\hline NA & $16.9(6.6)$ & \\
\hline
\end{tabular}


medRxiv preprint doi: https://doi.org/10.1101/2021.11.17.21266441; this version posted February 23, 2022. The copyright holder for this preprint (which was not certified by peer review) is the author/funder, who has granted medRxiv a license to display the preprint in

It is made available under a CC-BY-ND 4.0 International license .

Table 2: Comparison of vaccination responders and non-responders among AIRD-patients taking MTX

\begin{tabular}{|c|c|c|c|}
\hline & $\begin{array}{c}\text { Responders } \\
(n=55)\end{array}$ & $\begin{array}{l}\text { Non-Responders } \\
(n=9)\end{array}$ & P value \\
\hline Age, mean (SD) & $59.5(12.9)$ & $70.3(6.67)$ & 0.001 \\
\hline Female, $\mathrm{n}(\%)$ & $42(76.4)$ & $3(33.3)$ & 0.010 \\
\hline BMI, mean (SD) & $25.4(4.09)$ & $26.6(3.70)$ & 0.389 \\
\hline Medication & & & 0.616 \\
\hline MTX-Mono, n (\%) & $23(41.8)$ & $3(33.3)$ & \\
\hline MTX+prednisolone, n (\%) & $8(14.5)$ & $4(44.4)$ & \\
\hline MTX+Anti-TNF $\alpha, n(\%)^{\ddagger}$ & $10(18.2)$ & $1(11.1)$ & \\
\hline MTX+Anti-TNF $\alpha+$ prednisolone, $n(\%)^{\ddagger}$ & $6(10.9)$ & $1(11.1)$ & \\
\hline $\mathrm{MTX}+\mathrm{HCQ}, \mathrm{n}(\%)$ & $2(3.6)$ & 0 & \\
\hline MTX+Leflunomide, $\mathrm{n}(\%)^{\S}$ & $3(5.5)$ & 0 & \\
\hline MTX+Anti-IL-17, n (\%) ${ }^{* *}$ & $2(3.6)$ & 0 & \\
\hline MTX+Anti-IL-12/23, n (\%) ${ }^{++}$ & $1(1.8)$ & 0 & \\
\hline MTX dose [mg/week], mean (SD) & $13.0(4.29)$ & $14.2(4.33)$ & 0.469 \\
\hline MTX oral application, n (\%) & $25(45.5)$ & $1(11.1)$ & 0.057 \\
\hline Additional prednisolone, n (\%) & $15(27.3)$ & $5(55.6)$ & 0.103 \\
\hline Prednisolone dose [mg/day], mean (SD) & $2.5(1.4)$ & $3.8(1.6)$ & 0.174 \\
\hline Vaccination & & & 0.609 \\
\hline BNT162b2, n (\%) & $39(70.9)$ & $8(88.9)$ & \\
\hline mRNA-1273, n (\%) & $7(12.7)$ & $1(11.1)$ & \\
\hline AZD1222, n (\%) & $7(12.7)$ & 0 & \\
\hline AZD1222 + BNT162b2, n (\%) & $2(3.6)$ & 0 & \\
\hline vaccine interval in days, mean (SD) & $42(15)$ & $31(9)$ & 0.011 \\
\hline days from second vaccination, mean (SD) & $30(22)$ & $40(22)$ & 0.259 \\
\hline MTX-hold, n (\%) & $30(54.5)$ & $1(11.1)$ & 0.017 \\
\hline for both vaccinations, $\mathrm{n}$ & $23(41.8)$ & $1(11.1)$ & \\
\hline for only the 1 st vaccination, $n$ & $2(3.6)$ & 0 & \\
\hline for only the 2 nd vaccination, $n$ & $5(9.0)$ & 0 & \\
\hline
\end{tabular}

\footnotetext{
${ }^{*}$ Defined by neutralising capacity against SARS-CoV-2 $\geq 30 \%$

${ }^{+} \mathrm{P}$ values were calculated using the exact unconditional z-pooled test for binary variables (female, MTX oral application, additional prednisolone, MTX hold), Chi ${ }^{2}$ test for categorical variables (medication, vaccination) and unpaired $t$ test with Welch's correction for continuous variables.

${ }^{\ddagger}$ Adalimumab, Certolizumab, Etanercept, Golimumab, Infliximab.

${ }^{\S}$ Additional low dose prednisolone for $\mathrm{n}=1$.

${ }^{* *}$ Secukinumab.

${ }^{+}$Ustekinumab.

MTX, methotrexate; $\mathrm{HCQ}$, hydroxychloroquine.
} 
medRxiv preprint doi: https://doi.org/10.1101/2021.11.17.21266441; this version posted February 23, 2022. The copyright holder for this preprint (which was not certified by peer review) is the author/funder, who has granted medRxiv a license to display the preprint in It is made available under a CC-BY-ND 4.0 International license .

Table 3: Association of neutralising capacity and Anti-RBD-IgG concentration with selected covariates in univariate and multivariable analyses ( $n=64)$.

RR $\frac{\text { univariate analysis }}{\mathrm{p} \text { value } \quad 95 \% \mathrm{Cl}}$

\section{Outcome: Anti-RBD-IgG concentration $>1 \mathrm{~S} / \mathrm{CO}$}

\begin{tabular}{|c|c|c|c|c|c|c|c|}
\hline Female & 1.18 & 0.280 & $0.88 ; 1.58$ & 0.60 & 1.23 & 0.125 & $0.94 ; 1.62$ \\
\hline Age in years $\pi$ & 0.93 & $<0.001$ & $0.89 ; 0.97$ & 0.89 & 0.94 & 0.001 & $0.90 ; 0.97$ \\
\hline $\begin{array}{r}\text { MTX } \\
\text { monotherapy }\end{array}$ & 1.00 & & & 0.63 & 1.00 & & \\
\hline $\begin{array}{r}\text { MTX + } \\
\text { prednisolone }\end{array}$ & 0.79 & 0.284 & $0.51 ; 1.22$ & & 0.86 & 0.415 & $0.60 ; 1.24$ \\
\hline $\begin{array}{r}\text { MTX } \\
\text { combination } \\
\pm \\
\text { prednisolone }\end{array}$ & 1.05 & 0.687 & $0.84 ; 1.30$ & & 1.04 & 0.693 & $0.86 ; 1.25$ \\
\hline $\begin{array}{r}\text { MTX dose in } \\
\text { mg }\end{array}$ & 0.99 & 0.688 & $0.97 ; 1.02$ & 0.54 & & & \\
\hline MTX hold & 1.39 & 0.006 & $1.10 ; 1.76$ & 0.74 & 1.27 & 0.020 & $1.04 ; 1.56$ \\
\hline $\begin{array}{l}\text { Vaccine } \\
\text { interval }\end{array}$ & 1.006 & 0.016 & $\begin{array}{c}1.001 ; \\
1.010\end{array}$ & 0.75 & 1.004 & 0.024 & $\begin{array}{c}1.0006 \\
1.008\end{array}$ \\
\hline \multicolumn{8}{|c|}{ Outcome: neutralisation capacity $\geq 30 \%$} \\
\hline Female & 1.36 & 0.055 & $0.99 ; 1.87$ & 0.72 & 1.43 & 0.012 & $1.08 ; 1.90$ \\
\hline Age in years $\pi$ & 0.96 & 0.008 & $0.92 ; 0.99$ & 0.77 & 0.96 & 0.018 & $0.93 ; 0.99$ \\
\hline $\begin{array}{r}\text { MTX } \\
\text { monotherapy }\end{array}$ & 1.00 & & & 0.68 & 1.00 & & \\
\hline $\begin{array}{r}\mathrm{MTX}+ \\
\text { prednisolone }\end{array}$ & 0.75 & 0.194 & $0.49 ; 1.15$ & & 0.75 & 0.099 & $0.53 ; 1.06$ \\
\hline $\begin{array}{r}\text { MTX } \\
\text { combination } \\
\pm \\
\text { prednisolone }\end{array}$ & 1.04 & 0.641 & $0.87 ; 1.25$ & & 0.98 & 0.838 & $0.84 ; 1.15$ \\
\hline $\begin{array}{r}\text { MTX dose in } \\
\text { mg }\end{array}$ & 0.99 & 0.452 & $0.97 ; 1.01$ & 0.58 & & & \\
\hline MTX hold & 1.28 & 0.019 & $1.04 ; 1.57$ & 0.72 & 1.17 & 0.039 & $1.00 ; 1.38$ \\
\hline $\begin{array}{l}\text { Vaccine } \\
\text { interval }\end{array}$ & 1.002 & 0.235 & $\begin{array}{c}0.999 \\
1.006\end{array}$ & 0.63 & 1.001 & 0.423 & $0.998 ; 1.004$ \\
\hline
\end{tabular}

$\mathrm{AUC}=$ Area under Curve; $95 \% \mathrm{Cl}=95 \%$ confidence interval; $\mathrm{RR}=$ relative risk.

I I Relative risk was estimated by a Poisson generalized linear model with robust error variances and log link function in univariate and multivariable analyses according to Zou ${ }^{19}$

$\llbracket$ relative risk for increase by 5 years 
Table 4: Association of Neutralising capacity and Anti-RBD-IgG concentration with MTX-intake timing using linear regression analysis ( $n=64)^{*}$

\begin{tabular}{|c|c|c|c|c|c|c|c|c|c|c|c|c|}
\hline & \multicolumn{4}{|c|}{ All patients ${ }^{\dagger}$} & \multicolumn{4}{|c|}{ Patients $<60$ years $^{\ddagger}$} & \multicolumn{4}{|c|}{ Patients $\geq 60$ years $^{\ddagger}$} \\
\hline & $\beta$ & $P$ value & $95 \% \mathrm{Cl}$ & $\beta_{\mathrm{st}}$ & $\beta$ & $P$ value & $95 \% \mathrm{Cl}$ & $\beta_{\mathrm{st}}$ & $\beta$ & $P$ value & $95 \% \mathrm{Cl}$ & $\beta_{\text {st }}$ \\
\hline \multicolumn{13}{|c|}{ neutralisation capacity } \\
\hline $\mathrm{T}_{\mathrm{BV}}$ & 0.00 & 0.976 & $-0.20 ; 0.19$ & 0.00 & -0.05 & 0.749 & $-0.37 ; 0.27$ & -0.06 & 0.04 & 0.807 & $-0.26 ; 0.33$ & 0.03 \\
\hline $\mathrm{T}_{\mathrm{AV}}$ & 0.19 & 0.005 & $0.06 ; 0.32$ & 0.30 & 0.09 & 0.301 & $-0.09 ; 0.28$ & 0.20 & 0.24 & 0.012 & $0.06 ; 0.43$ & 0.32 \\
\hline $\mathrm{T}_{\mathrm{BV}} \geq 10$ days & -0.85 & 0.367 & $-2.73 ; 1.02$ & -0.08 & -0.36 & 0.789 & $-3.12 ; 2.40$ & -0.05 & -1.98 & 0.094 & $-4.31 ; 0.35$ & -0.13 \\
\hline $\mathrm{T}_{\mathrm{AV}} \geq 10$ days & 2.00 & 0.008 & $0.53 ; 3.47$ & 0.27 & -0.22 & 0.833 & $-2.34 ; 1.91$ & -0.04 & 2.91 & 0.001 & $1.29 ; 4.53$ & 0.36 \\
\hline $\mathrm{T}_{\mathrm{BV}}+\mathrm{T}_{\mathrm{AV}}$ & 0.13 & 0.035 & $0.01 ; 0.25$ & 0.25 & 0.04 & 0.626 & $-0.13 ; 0.22$ & 0.11 & 0.18 & 0.039 & $0.01 ; 0.35$ & 0.29 \\
\hline \multicolumn{13}{|l|}{ anti-RBD-IgG } \\
\hline $\mathrm{T}_{\mathrm{BV}}$ & 0.80 & 0.244 & $-0.56 ; 2.15$ & 0.09 & 0.47 & 0.575 & $-1.24 ; 2.17$ & 0.10 & 1.26 & 0.236 & $-0.86 ; 3.39$ & 0.12 \\
\hline $\mathrm{T}_{\mathrm{AV}}$ & 1.02 & 0.016 & $0.19 ; 1.84$ & 0.19 & 0.11 & 0.739 & $-0.56 ; 0.78$ & 0.04 & 1.63 & 0.036 & $0.12 ; 3.14$ & 0.22 \\
\hline $\mathrm{T}_{\mathrm{BV}} \geq 10$ days & -1.86 & 0.777 & $-14.96 ; 11.24$ & -0.02 & 0.49 & 0.950 & $-15.49 ; 16.47$ & 0.01 & -6.43 & 0.323 & $-19.43 ; 6.57$ & -0.05 \\
\hline $\mathrm{T}_{\mathrm{AV}} \geq 10$ days & 13.70 & 0.004 & $4.60 ; 22.79$ & 0.21 & -2.53 & 0.583 & $-11.96 ; 6.90$ & -0.07 & 20.03 & 0.005 & $6.57 ; 33.50$ & 0.26 \\
\hline$T_{B V}+T_{A V}$ & 0.95 & 0.003 & $0.33 ; 1.58$ & 0.22 & 0.21 & 0.487 & $-0.41 ; 0.84$ & 0.09 & 1.51 & 0.019 & $0.26 ; 2.77$ & 0.26 \\
\hline
\end{tabular}

\footnotetext{
${ }^{*}$ One patient who did not hold MTX could not recall on which exact day MTX was taken and was therefore only considered for calculations of $\mathrm{T}_{\mathrm{BV}}+\mathrm{T}_{\mathrm{AV}}(=7 \mathrm{days})$.

+ adjusted for female, age, MTX monotherapy, MTX + prednisolone, MTX combination \pm prednisolone, vaccine interval.

‡ adjusted for female, MTX monotherapy, MTX + prednisolone, MTX combination \pm prednisolone, vaccine interval.

$\beta$ (unstandardized beta coefficient); $\beta$ st (standardized beta coefficient); TBV (time before vaccination), time between last MTX-intake and vaccination; TAV (time after vaccination), time between vaccination and re-intake of MTX; TBV+TAV, MTX-interval at the time of vaccination
} 
medRxiv preprint doi: https://doi.org/10.1101/2021.11.17.21266441; this version posted February 23, 2022. The copyright holder for this preprint (which was not certified by peer review) is the author/funder, who has granted medRxiv a license to display the preprint in

It is made available under a CC-BY-ND 4.0 International license.

Supplementary table 1: Characteristics of MTX-patients and control-group

\begin{tabular}{|c|c|c|c|c|}
\hline & $\begin{array}{l}\text { MTX-therapy } \\
(n=64)\end{array}$ & $\begin{array}{l}\text { No therapy } \\
(n=21)\end{array}$ & $\begin{array}{c}\text { All } \\
(n=85)\end{array}$ & P value $^{*}$ \\
\hline Age, mean (SD) & $61(13)$ & $61(14)$ & $61(13)$ & 0.899 \\
\hline Female, $\mathrm{n}(\%)$ & $45(70.3)$ & $19(90.5)$ & $64(75.3)$ & 0.069 \\
\hline $\mathrm{BMI}$, mean (SD) & $25.6(4.0)$ & $23.8(3.9)$ & $25.1(4.1)$ & 0.088 \\
\hline Rheumatic diagnosis & & & & $<0.001$ \\
\hline Rheumatoid arthritis, n (\%) & $44(68.6)$ & $3(14.3)$ & $47(55.3)$ & \\
\hline Psoriatic arthritis, $\mathrm{n}(\%)$ & $7(10.9)$ & $2(9.5)$ & $9(10.6)$ & \\
\hline Systemic sclerosis, n (\%) & $3(4.7)$ & $8(38.1)$ & $11(12.9)$ & \\
\hline Others, $\mathrm{n}(\%)^{+}$ & $10(15.6)$ & $8(38.1)$ & $18(21.2)$ & \\
\hline Vaccination & & & & 0.542 \\
\hline BNT162b2, n (\%) & $47(73.4)$ & $16(76.2)$ & $63(74.1)$ & \\
\hline mRNA-1273, n (\%) & $8(12.5)$ & $2(9.5)$ & $10(11.8)$ & \\
\hline AZD1222, n (\%) & $7(10.9)$ & $1(4.8)$ & $8(9.4)$ & \\
\hline AZD1222 + mRNA, n (\%) & $2(3.1)$ & $2(9.5)$ & $4(4.7)$ & \\
\hline vaccine interval in days, mean (SD) & $40.4(15.0)$ & $38.6(21.4)$ & $40.0(16.7)$ & 0.725 \\
\hline \multicolumn{5}{|l|}{ Immune response } \\
\hline days from $2^{\text {nd }}$ vaccination, mean (SD) & $32(22)$ & $31(20)$ & $32(22)$ & 0.807 \\
\hline Anti-RBD-lgG [S/CO], mean (SD) & $5.0(3.3)$ & $6.8(2.0)$ & $5.4(3.1)$ & 0.004 \\
\hline Neutralising capacity [\%], mean (SD) & $71.8(28.3)$ & $92.4(8.6)$ & $76.9(26.4)$ & $<0.001$ \\
\hline Responders, $\mathrm{n}(\%)^{5}$ & $55(85.9)$ & $21(100)$ & $76(89.4)$ & 0.076 \\
\hline
\end{tabular}

${ }^{*} \mathrm{P}$ values were calculated using the exact unconditional $z$-pooled test for binary variables (female, responders), $\mathrm{Chi}^{2}$ test for categorical variables (rheumatic diagnosis, vaccination) and unpaired t test with Welch's correction for continuous variables.

${ }^{+}$For MTX group: ANCA-associated vasculitis $(n=1)$, Axial spondyloarthritis $(n=2)$, Polymyalgia rheumatica $(n=3)$, Primary Sjogren's syndrome $(n=1)$, Myositis $(n=2)$, Systemic lupus erythematosus $(n=1)$.

For no therapy group: Axial spondyloarthritis $(n=2)$, Polymyalgia rheumatica $(n=1)$, Primary Sjogren's syndrome $(n=2)$, Systemic lupus erythematosus $(n=1)$, Familial Mediterranean fever $(n=1)$, peripheral spondyloarthritis $(n=1)$. ${ }^{\ddagger}$ MTX group: AZD1222 + BNT162b2 $(n=2)$. No-therapy-group: AZD1222 + BNT162b2 $(n=1)$, AZD1222 + mRNA$1273(n=1)$.

${ }^{\S}$ Defined by neutralising capacity against SARS-CoV $-2 \geq 30 \%$.

MTX, methotrexate. 
medRxiv preprint doi: https://doi.org/10.1101/2021.11.17.21266441; this version posted February 23, 2022. The copyright holder for this preprint (which was not certified by peer review) is the author/funder, who has granted medRxiv a license to display the preprint in

It is made available under a CC-BY-ND 4.0 International license .

Supplementary table 2: Comparison of vaccination responders and non-responders (anti-RBD-IgG levels)

\begin{tabular}{|c|c|c|c|}
\hline & $\begin{array}{c}\text { Responders } \\
(n=51)\end{array}$ & $\begin{array}{c}\text { Non-Responders } \\
(n=13)\end{array}$ & $P$ value \\
\hline Age, mean (SD) & $58(12)$ & $73(7)$ & $<0.001$ \\
\hline Female, $\mathrm{n}(\%)$ & $38(74.5)$ & $7(53.8)$ & 0.163 \\
\hline $\mathrm{BMI}$, mean (SD) & $25.3(3.9)$ & $26.5(4.7)$ & 0.395 \\
\hline Medication & & & 0.524 \\
\hline MTX-Mono, n (\%) & $22(43.1)$ & $4(30.8)$ & \\
\hline MTX+prednisolone, n (\%) & $7(13.7)$ & $5(38.5)$ & \\
\hline MTX+Anti-TNF $\alpha, n(\%)^{\ddagger}$ & $9(17.6)$ & $2(15.4)$ & \\
\hline MTX+Anti-TNF $\alpha+$ prednisolone, $n(\%)^{\ddagger}$ & $5(9.8)$ & $2(15.4)$ & \\
\hline $\mathrm{MTX}+\mathrm{HCQ}, \mathrm{n}(\%)$ & $2(3.9)$ & 0 & \\
\hline MTX+Leflunomide, $\mathrm{n}(\%)^{\S}$ & $3(5.9)$ & 0 & \\
\hline MTX+Anti-IL-17, n (\%)** & $2(3.9)$ & 0 & \\
\hline MTX+Anti-IL-12/23, n (\%) ${ }^{++}$ & $1(2.0)$ & 0 & \\
\hline MTX dose [mg/week], mean (SD) & $13.2(4.3)$ & $13.1(4.2)$ & 0.935 \\
\hline MTX oral application, n (\%) & $23(45.1)$ & $3(23.1)$ & 0.187 \\
\hline Additional prednisolone, $\mathrm{n}$ (\%) & $13(25.5)$ & $7(53.8)$ & 0.054 \\
\hline Prednisolone dose [mg/day], mean (SD) & $2.8(1.3)$ & $2.9(2.0)$ & 0.890 \\
\hline Vaccination & & & 0.336 \\
\hline BNT162b2, n (\%) & $35(68.6)$ & $12(92.3)$ & \\
\hline mRNA-1273, n (\%) & $7(13.7)$ & $1(7.7)$ & \\
\hline AZD1222, n (\%) & $7(13.7)$ & 0 & \\
\hline AZD1222 + BNT162b2, n (\%) & $2(3.9)$ & 0 & \\
\hline vaccine interval in days, mean (SD) & $43(15)$ & $30(9)$ & $<0.001$ \\
\hline days from second vaccination, mean (SD) & $30(22)$ & $39(21)$ & 0.174 \\
\hline MTX-hold, n (\%) & $30(58.8)$ & $1(7.7)$ & 0.002 \\
\hline for both vaccinations, $\mathrm{n}$ & 23 & 1 & / \\
\hline for only the 1 st vaccination, $n$ & 2 & 0 & / \\
\hline for only the 2 nd vaccination, $n$ & 5 & 0 & I \\
\hline
\end{tabular}

\footnotetext{
${ }^{*}$ Defined by anti-SARS-CoV-2-RBD-lgG $>1.00 \mathrm{~S} / \mathrm{CO}$.

${ }^{+} \mathrm{P}$ values were calculated using the exact unconditional z-pooled test for binary variables (female, MTX oral application, additional prednisolone, MTX hold), $\mathrm{Chi}^{2}$ test for categorical variables (medication, vaccination) and unpaired $t$ test with Welch's correction for continuous variables.

${ }^{\ddagger}$ Adalimumab, Certolizumab, Etanercept, Golimumab, Infliximab.

${ }^{\S}$ Additional lowdose prednisolone for $\mathrm{n}=1$.

${ }^{* *}$ Secukinumab.

${ }^{+}$Ustekinumab.

MTX, methotrexate; $\mathrm{HCQ}$, hydroxychloroquine.
} 
medRxiv preprint doi: $h$ ttps://doi.org/10.1101/2021.11.17.21266441; this version posted February 23, 2022. The copyright holder for this preprint (which was not certified by peer review) is the author/funder, who has granted medRxiv a license to display the preprint in

It is made available under a CC-BY-ND 4.0 International license .

\section{Figures}

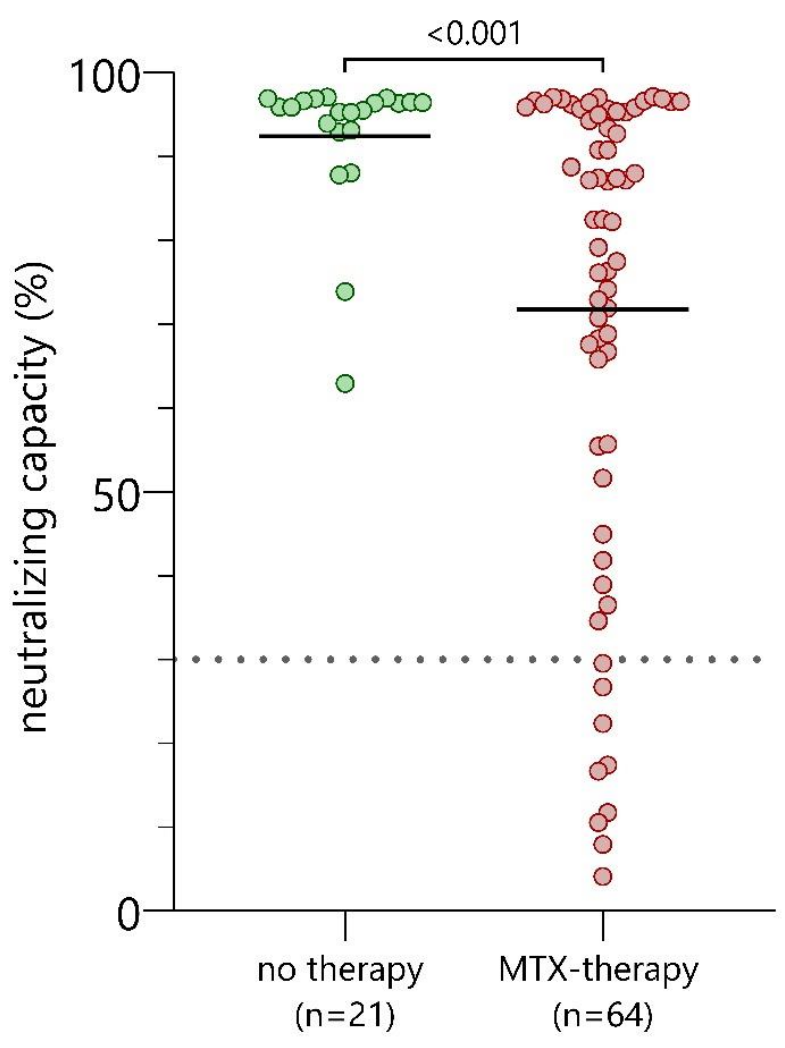

Figure 1: Comparison of neutralising capacity in AIRD patients without immunosuppression and with MTX therapy. Neutralising capacity measured using surrogate virus neutralisation test after second vaccination in MTX-patients $(n=64)$ represented by red dots vs. AIRD patients who were under no immunosuppressive therapy during both vaccinations $(n=21)$ represented by green dots. $P$ values were calculated using the parametric unpaired $t$ test with Welch's correction. 
medRxiv preprint doi: $h$ ttps://doi.org/10.1101/2021.11.17.21266441; this version posted February 23, 2022. The copyright holder for this preprint (which was not certified by peer review) is the author/funder, who has granted medRxiv a license to display the preprint in It is made available under a CC-BY-ND 4.0 International license.
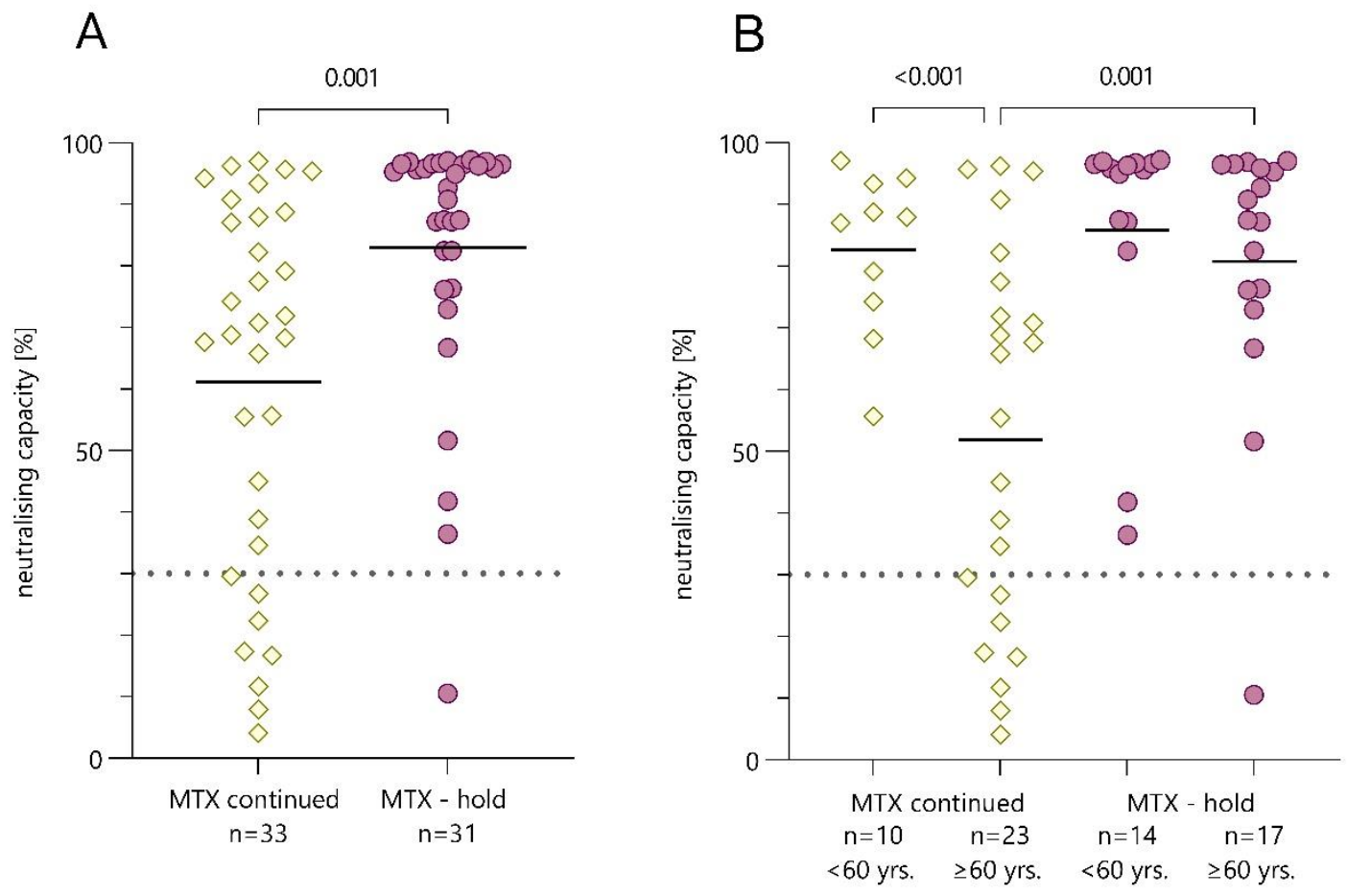

Figure 2: Comparison of AIRD patients who continued or held their MTX during the COVID-19 vaccination. (A) Neutralising capacity measured using surrogate virus neutralisation test compared between patients who held MTX during vaccination $(n=33)$ and patients who continued MTX-therapy ( $n=31)$. (B) Neutralising capacity differentiated by age groups $<60$ years and $\geq 60$ years. $P$ values were calculated using the parametric unpaired $t$ test with Welch's correction. Dotted line marks the cut-off value following manufacturer's protocol ( $\geq 30 \%)$. Yellow squares represent patients who continued MTX-therapy, purple dots represent patients who held MTX for at least one vaccination. 


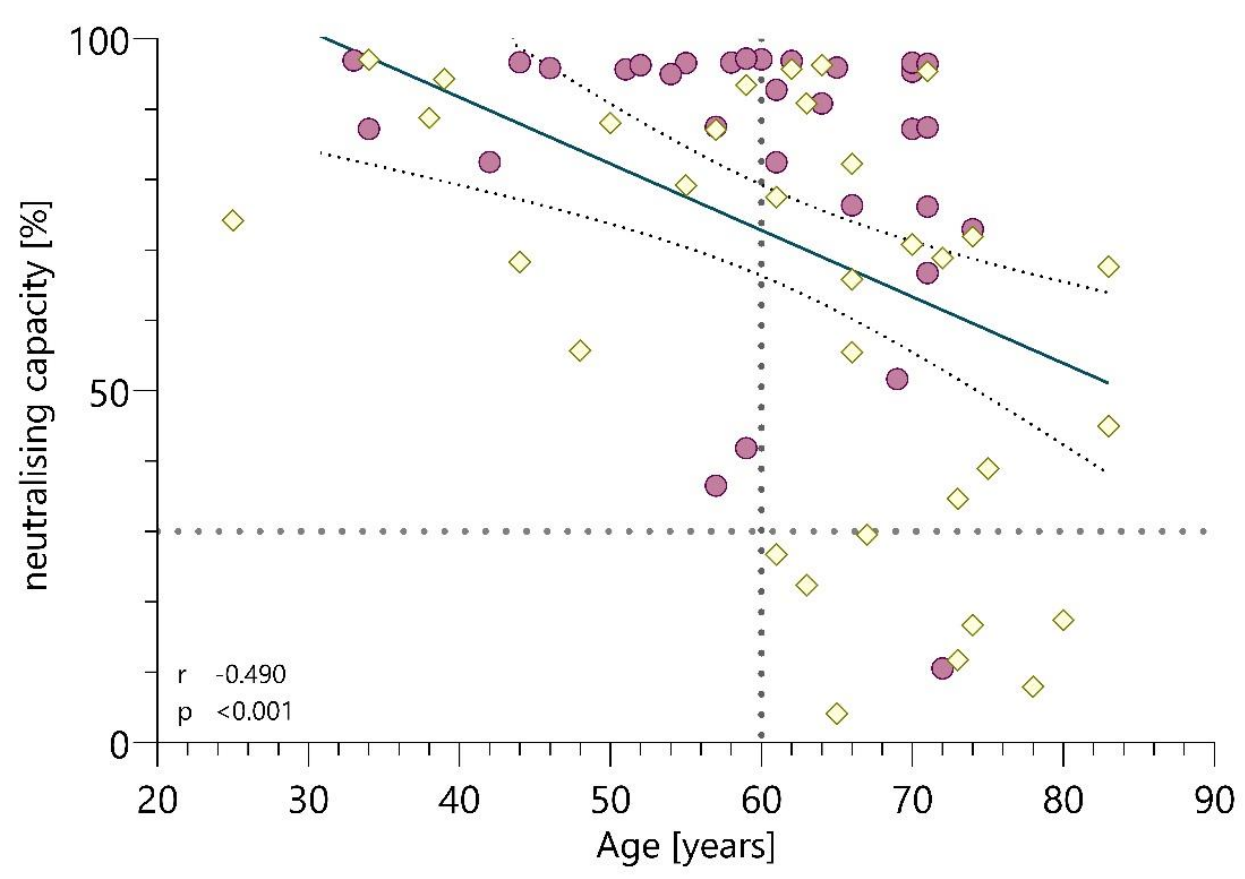

Figure 3: Correlation of Age and neutralising capacity measured using surrogate virus neutralisation test. Purple dots represent patients who held MTX during vaccination $(n=31)$, yellow squares represent patients who continued MTX-therapy $(n=33)$. Neutralising antibodies were measured using a surrogate virus neutralisation test. Dotted lines mark the cut-off value following manufacturer's protocol ( $\geq 30 \%$ ) and the cut-off age used for further analysis at 60 years. $P$ value and correlation coefficient were calculated using the Spearman Rank correlation.

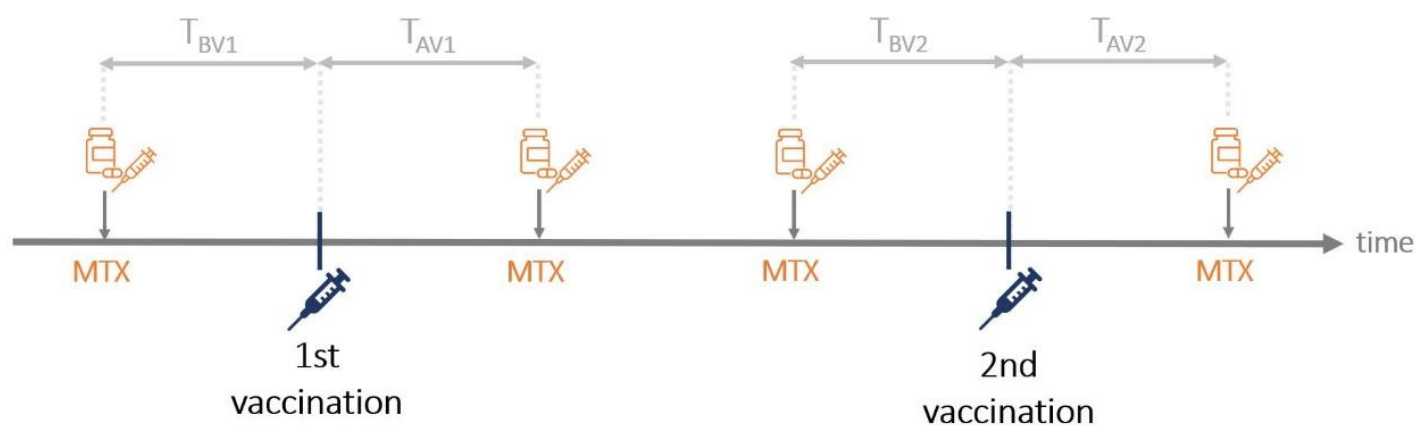

Figure 4: Visualization of analysed time intervals. Time between MTX-intakes and COVID19 vaccinations were assessed for each vaccination and added together to receive the total time before vaccinations (TBV=TBV1+TBV2) and after vaccinations (TAV=TAV1+TAV2). The MTXinterval was defined as the total durations between two MTX intakes at the time of vaccination $(T A V+T B V)$. 


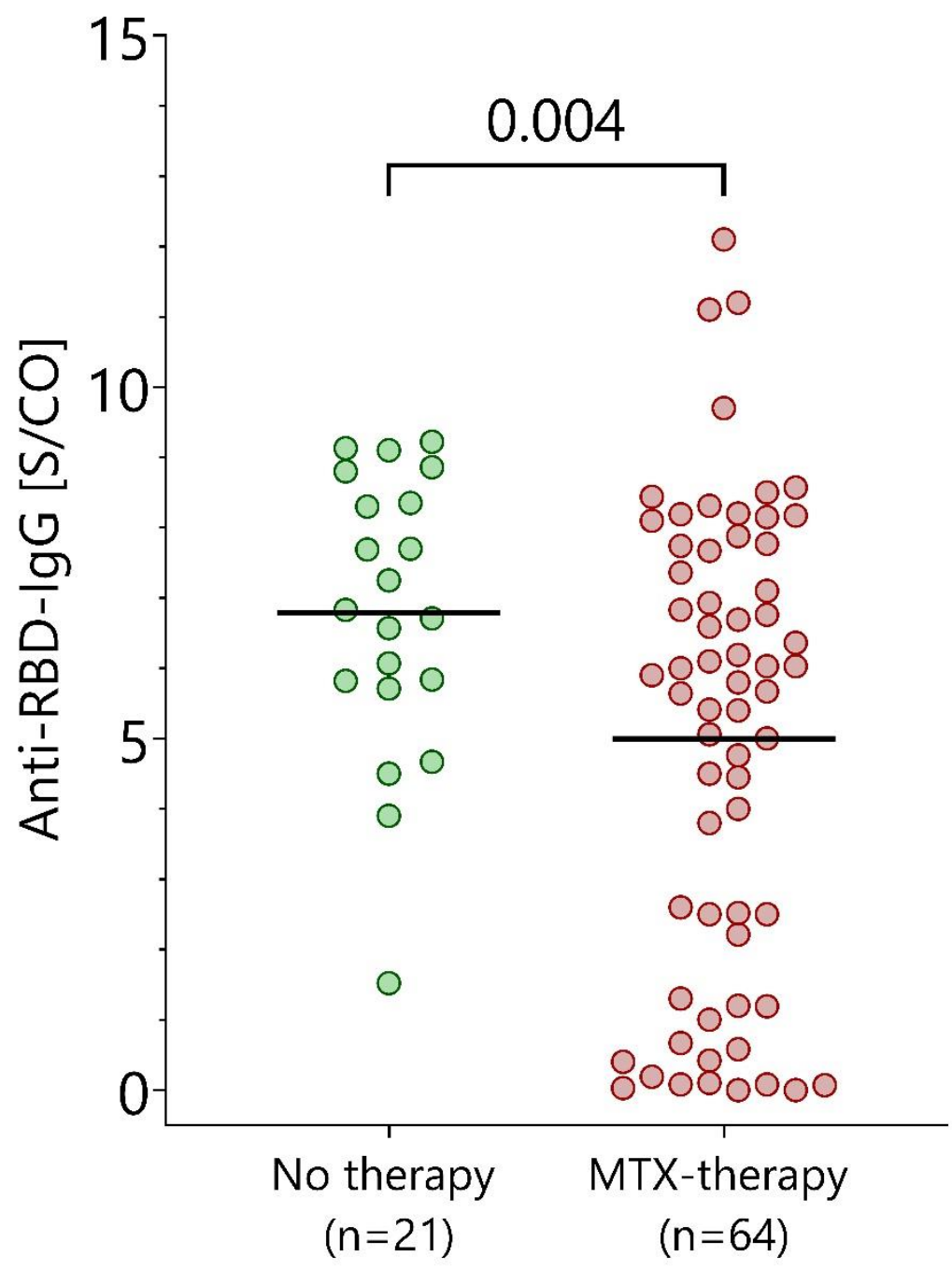

Supplementary figure 1: Comparison of anti-RBD-IgG-antibody levels in AIRD patients without immunosuppression and with MTX therapy. Anti-RBD-IgG-antibody levels after second vaccination in MTX-patients $(n=64)$ represented by red dots vs. patients who were under no immunosuppressive therapy during both vaccinations $(n=21)$ represented by green dots. $P$ values were calculated using the parametric unpaired t test with Welch's correction. 
medRxiv preprint doi: $h$ ttps://doi.org/10.1101/2021.11.17.21266441; this version posted February 23, 2022. The copyright holder for this preprint (which was not certified by peer review) is the author/funder, who has granted medRxiv a license to display the preprint in It is made available under a CC-BY-ND 4.0 International license.

A

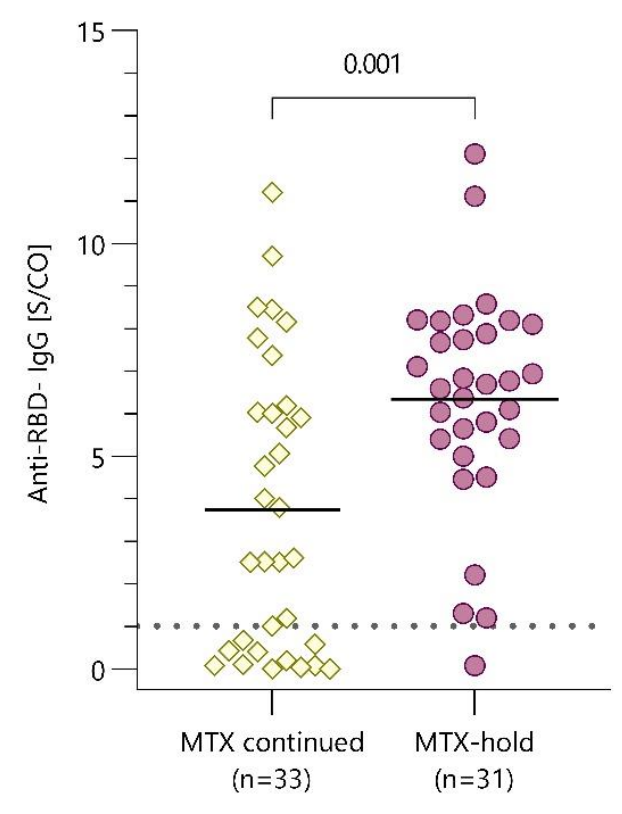

B

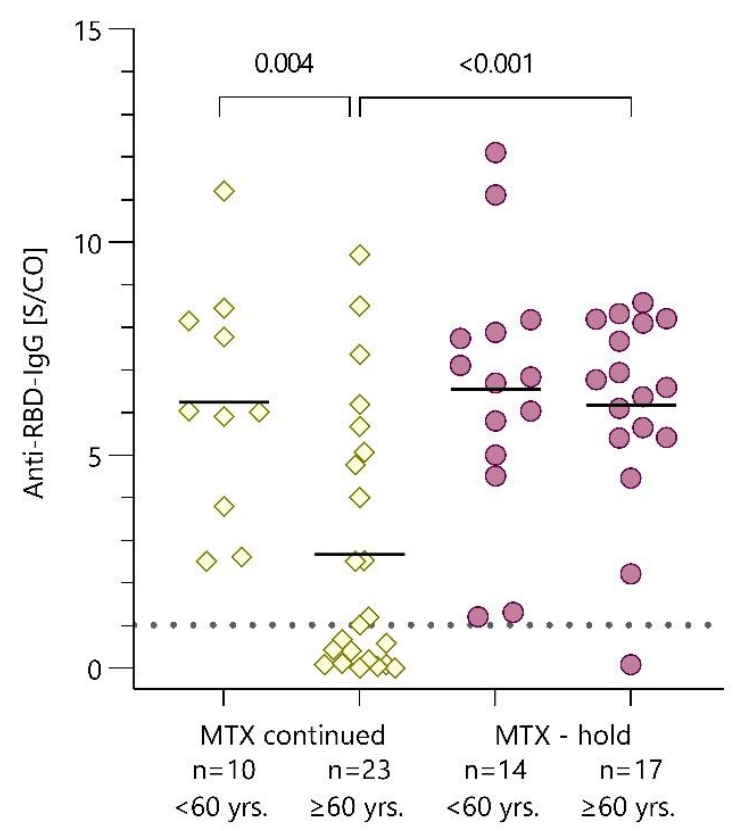

Supplementary figure 2: Comparison of AIRD patients who continued or held their MTX during the COVID-19 vaccination. (A) Anti-RBD-IgG concentrations compared between patients who held MTX during vaccination ( $n=33)$ and patients who continued MTX-therapy $(n=31)$. (B) Anti-RBD-IgG concentrations differentiated by age groups $<60$ years and $\geq 60$ years. $P$ values were calculated using the parametric unpaired t test with Welch's correction. Dotted line marks the cut-off value following manufacturer's protocol (>1 S/CO). Yellow squares represent patients who continued MTX-therapy, purple dots represent patients who held MTX for at least one vaccination. 
medRxiv preprint doi: $h$ ttps://doi.org/10.1101/2021.11.17.21266441; this version posted February 23, 2022. The copyright holder for this preprint (which was not certified by peer review) is the author/funder, who has granted medRxiv a license to display the preprint in It is made available under a CC-BY-ND 4.0 International license.
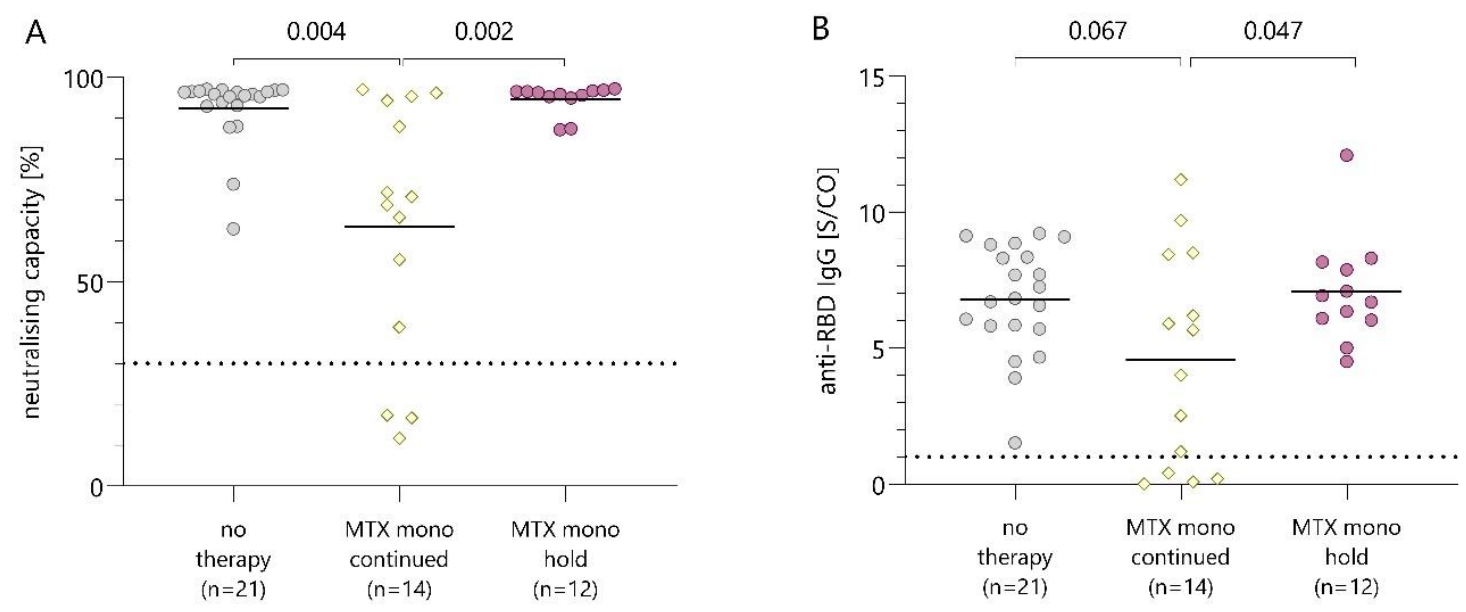

Supplementary figure 3: Comparison of antibody response in AIRD patients without immunosuppressive medication and MTX monotherapy patients who continued $(n=14)$ or held $(n=12)$ their MTX during COVID-19 vaccination. (A) Neutralising capacity measured using surrogate virus neutralisation test. Dotted line marks the cut-off value following manufacturer's protocol ( $\geq 30 \%$ ). (B) Anti-RBD-IgG-antibody levels after second COVID-19 vaccination. Dotted line marks the cut-off antibody concentration for adequate humoral immune response following manufacturer's protocol (>1 S/CO).

$P$ values were calculated using the parametric unpaired $t$ test with Welch's correction. Yellow squares represent patients who continued MTX-therapy, purple dots represent patients who held MTX for at least one vaccination. 
medRxiv preprint doi: $h$ ttps://doi.org/10.1101/2021.11.17.21266441; this version posted February 23, 2022. The copyright holder for this preprint (which was not certified by peer review) is the author/funder, who has granted medRxiv a license to display the preprint in It is made available under a CC-BY-ND 4.0 International license .

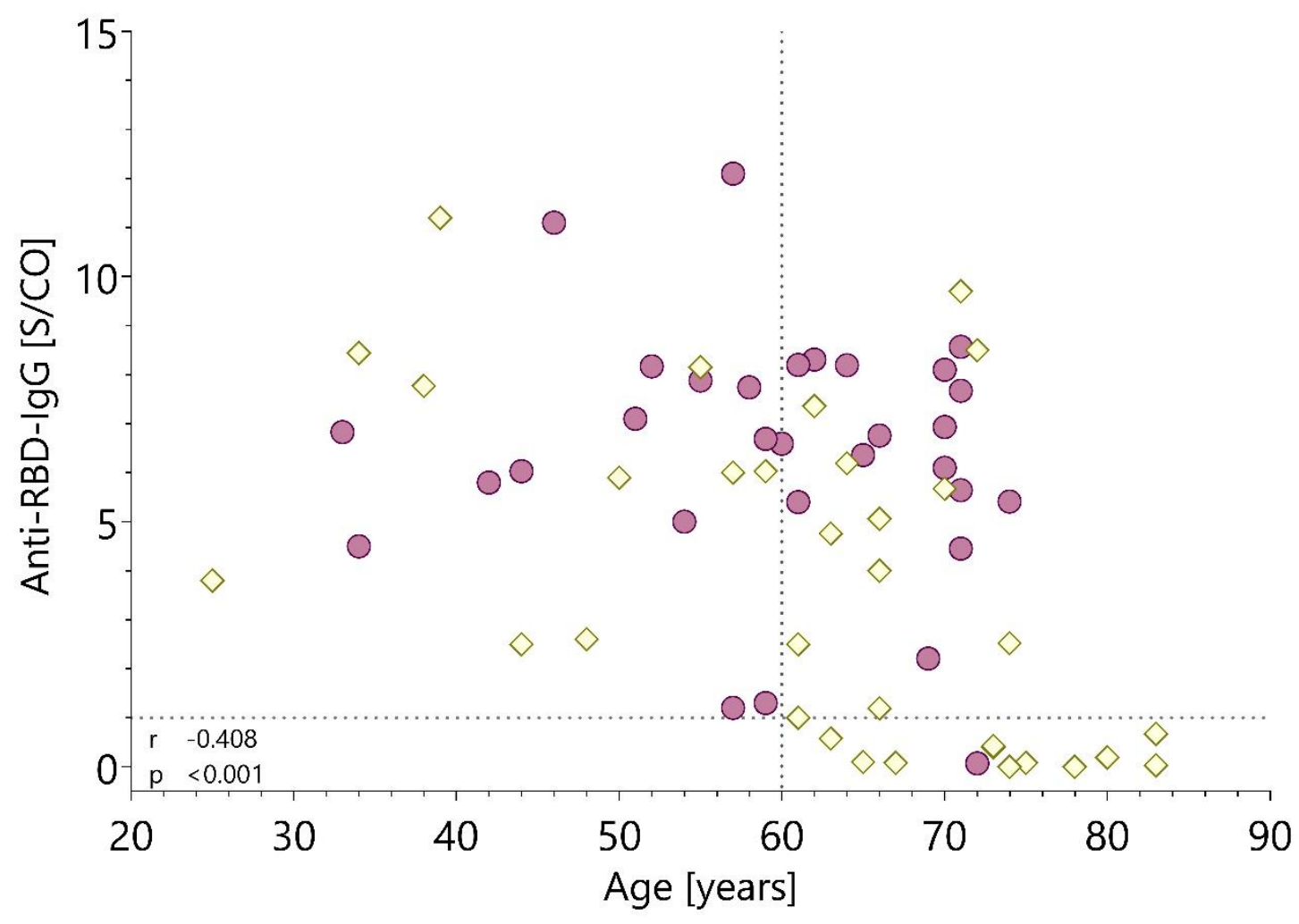

Supplementary figure 4: Correlation of Age and Anti-RBD-IgG-Antibody concentrations.

Purple dots represent patients who held MTX during vaccination $(n=31)$, yellow squares represent patients who continued MTX-therapy (n=33). Dotted lines mark the cut-off antibody concentration for adequate humoral immune response following manufacturer's protocol (>1 $S / C O)$ and the cut-off age observed for this cohort at 60 years. $P$ value and correlation coefficient were calculated using the Spearman Rank correlation. 